\title{
Study of Stem Cell Therapy in Coronary Artery Bypass Grafting Patients Post Myocardial Infarction
}

\author{
Kamal S Ayyat ${ }^{1,2 *}$, Ahmed M Deebis ${ }^{1}$, Nader A Elboray ${ }^{1}$, Mohamed A Ghaly ${ }^{1}$ and Kenneth R McCurry ${ }^{2}$ \\ ${ }^{1}$ Department of Cardiothoracic Surgery, Faculty of Medicine, Zagazig University, Egypt \\ ${ }^{2}$ Department of Thoracic and Cardiovascular Surgery, Cleveland Clinic, USA
}

Received: May 02, 2019; Published: June 19, 2019

*Corresponding author: Kamal S Ayyat, Department of Cardiothoracic Surgery, Faculty of Medicine, Zagazig University, Zagazig, Egypt

\begin{abstract}
The prevalence of coronary heart diseases has increased over the last decades globally. This was accompanied by a subsequent increase in the prevalence of heart failure causing it to be a burden placed on healthcare systems. Thus, the focus of research attention has been directed towards regenerative medicine utilizing stem cells to restore cardiac function in these patients. The aim of this review is to update the literature with an evaluation of this approach from the surgical standpoint.
\end{abstract}

\section{Introduction}

Heart disease is the leading cause of death in the United States, with coronary heart diseases (CHD) as the first cause of deaths attributed to heart diseases. Globally, the prevalence of CHD has increased over the last decades [1]. This increase in the prevalence of CHD, as a major contributor to heart failure (HF), has caused an increase in the prevalence of HF which has become a burden placed on healthcare systems [2]. The deteriorated contractile capability of the heart post-myocardial infarction leads to a reduction in left ventricular ejection fraction (LVEF) causing ischemic cardiomyopathy. Thus, the amount of blood pumped into the circulation is insufficient. The failing contractile function of the heart increases the hemodynamic burden on the heart and causes mechanical stretch of the already stressed tissue contributing to $\mathrm{HF}[3,4]$. Ischemic cardiomyopathy is known to have an inevitable progressive nature with about $50 \%$ mortality during the first five years after diagnosis $[5,6]$.

The notion of the limited ability of the heart to repair itself combined with the unclear efficacy of coronary artery bypass grafting (CABG) surgery for these patients with poor cardiac function and the shortage of donor hearts for transplant had provided a rationale for an adjuvant therapy with CABG surgery that can restore cardiac function. Since 2001, the focus of attention has been the potential ability of stem cell therapy to restore deteriorated cardiac functions in these patient [7]. The promising results in animal studies have encouraged a lot of centers all over the world to launch their clinical trials to test the efficacy of this approach [8,9]. The aim of our review is to update the literature with the evaluation of cell therapy for IHD from the surgical standpoint.

\section{Myocardial Damage and Remodeling}

Coronary arteries occlusion causing myocardial ischemia is followed by sequelae of myocardial damage and remodeling. This damage becomes irreversible following the first 30 minutes of ischemia. During the following 6 hours, the affected cells undergo death, apoptosis, and necrosis. Thus, releasing intracellular proteins which initiate an inflammatory response with leukocytic infiltration of the infarcted area. Later, macrophages and lymphocytes undergo phagocytosis of dead myocardial cells stimulating fibroblasts which start proliferation and collagen production. Then, the affected myocardial tissue is replaced by a fibrotic scar $[10,11]$.

Replacement of contractile myocardial tissue by noncontractile scar tissue causes ventricular stress, which starts a cascade of morphological changes as an adaptive mechanism. The process of these morphological changes is known as cardiac remodeling, during which the fibroblasts proliferate to strengthen the scar tissue in order to prevent ventricular wall rupture. In addition, viable cardiomyocytes undergo hypertrophy as an adaptive mechanism for stress and pressure overload. The magnitude of cardiac remodeling is affected mainly by the extent of the myocardial infarction (MI) $[12,13]$. Although this compensatory process is crucial for maintaining cardiac functions post-infarction, it provokes long-term contractile 
dysfunction and formation of arrhythmogenic areas. Thus, leads to increased morbidity and mortality

\section{Ischemic Cardiomyopathy}

The deteriorated contractile capability of the heart leads to a reduction in LVEF. Thus, the amount of blood pumped into the circulation is insufficient. The failing contractile function of the heart increases the hemodynamic burden on the heart and causes mechanical stretch of the already stressed tissue contributing to heart failure $[3,4]$. As a compensatory mechanism, both the sympathetic nervous system and the renin-angiotensinaldosterone (RAA) system are activated leading to a rise in heart rate, vasoconstriction, fluid retention, and elevated systemic blood pressure [14]. All these effects increase the workload of the heart stretching the walls of the atria and ventricles. This stretch stimulates the increase of B-type natriuretic peptide (BNP), which tries to counteract the actions of both the sympathetic nervous system and the RAA system. However, this process contributes more to heart failure

Clinically, symptoms of patients with ischemic cardiomyopathy are dyspnea, fatigue, lower limb edema, and chest pain. Deteriorated contractile function of both ventricles leads to fluid accumulation in the lungs causing dyspnea which increases in supine position due to increased intrathoracic volume and pressure. The two most common classification systems used to quantify the degree of functional limitation caused by cardiac disease in adults are the New York Heart Association (NYHA) and the Canadian Cardiovascular Society (CCS) functional classification [15-19].

Despite the clear correlation between survival and the severity of the symptoms, patients with less severe symptoms may still have bad prognosis with a high risk of hospitalization and death. These patients are susceptible to sudden worsening of symptoms due to, for example, infections or arrhythmias that may lead to recurrent hospitalizations. That represents a major economic burden for any health-care system.18,19 Additionally, ischemic cardiomyopathy is known to have an inevitable progressive nature with about $50 \%$ mortality during the first five years after diagnosis [5,6].

\section{Myocardial Regeneration}

Traditionally, the heart was considered as a post-mitotic organ with permanent histological structure formed during embryogenesis that has no regenerative abilities. While most of the cardiac cells are derived from mesoderm, a few cardiac cells are derived from proepicardium and neural crest. During embryogenesis, Mesodermal cardiac cells are divided into two groups the first and second heart [20]. The first heart field forms the left ventricular cardiomyocytes. However, the specific progenitor cells and phenotypic markers for these cardiomyocytes are not established yet [21]. On the other hand, the second heart field cells express LIM-homeobox transcription factor ISL1 and show great multipotency. In vivo, they have the ability to form cardiomyocytes in the right ventricle, the outflow tract, the right and left atria, the proximal coronary arteries, and most of the conduction system [22]. Ex vivo, fetal cells with ISL1 expression can differentiate into cardiomyocytes, endothelial cells, and smooth muscle cells. These three cell types are found in the cardiac morphological structure [23].

Several studies have emerged since 1980's contradicting the traditional assumption of the regenerative inability of the adult human hearts. Some of these studies have shown the evidence proving the division ability of mitotic cells found in human adult hearts. This cell population known as cardiac progenitor cells (CPC) was found in different areas of the heart like the atrial appendages and outflow tract [24-28]. However, the exact marker profile for CPC is still debatable. Additionally, although, the regenerative capabilities of CPC has been proven, its ability to regenerate cardiomyocytes post-infarction is quite limited just 1 to $4 \%$ [25].

\section{Treatment for Ischemic Heart Failure}

\section{Surgical}

The role of CABG in treating CHD is limited to the presence of viable myocardium. CABG targets stunned myocardial tissue that can restore its contractile function after the returning of the blood flow [29]. Thus, the typically indicated patients for CABG are the ones with stable multiple vessel disease and LVEF greater than 35 to $40 \%$. Historically, in patients with left main coronary artery stenosis, left main equivalent disease, three-vessel, or twovessel coronary artery disease with more than $75 \%$ proximal stenosis in the left anterior descending (LAD) artery CABG was proven to improve survival [30-32]. In 2014, Windecker et al. conducted a huge meta-analysis including 100 trials and 93 553 patients to investigate whether revascularisation by CABG or percutaneous coronary intervention (PCI) could improve prognosis compared to medical treatment in patients with stable CHD. Their results showed that CABG was associated with improved survival [hazard ratio (HR) $0.80,95 \%$ confidence interval (CI) 0.70 to 0.91 ) and reduced risk of MI (HR 0.79, $95 \%$ CI 0.63 to 0.99 ) compared to medical treatment [33]. Surgical ventricular reconstruction (SVR) may provide further benefit for some CABG patients with scar tissue. The aim of this procedure is to restore normal cardiac morphology for some extent postinfarction by removing the scar tissue [34]. However, according to the guidelines, this procedure should be limited only to patients with severe heart failure symptoms, transmural scar tissue, and large left ventricle (LV) dimensions. Additionally, it should be only performed in centers with long experience in treating ischemic cardiomyopathy patients. For the most centers, effective medical treatment combined with CABG should be the treatment of choice for ischemic cardiomyopathy. Additional surgical intervention should be limited to some hemodynamics affecting complications like ischemic ventricular septal defect (VSD), ventricular wall rupture, or ischemic mitral regurge [35]. 


\section{Bone Marrow Stem Cell Therapy}

Currently, there are no guidelines on the use of BMSC transplant combined with CABG surgery in treating IHD. Broad meta-analyses evaluating cell therapies with different types of interventions have provided robust evidence to suggest a beneficial effect of these therapies on HF patients [36]. However, there is no updated meta-analysis specifically evaluating BMSC transplant with surgical intervention. Recently, the anticipated results of phase III of the PERFECT trial [37] in Europe and phase II of the IMPACT-CABG trial [38] in North America have been published. BMSCs can be delivered to the injured myocardium via different routes during CABG procedure. The three major techniques used for BMSCs delivery in most studies are: a) Intramyocardial injection, b) Intracoronary infusion and c) Retrograde coronary sinus delivery. These approaches are still in the stage of development and implementation. Although the optimum delivery method has yet to be determined, most clinical trials have reported a low frequency of complications regardless of method of BMSCs delivery proving the safety and feasibility of these methods.

\section{Intramyocardial Injection}

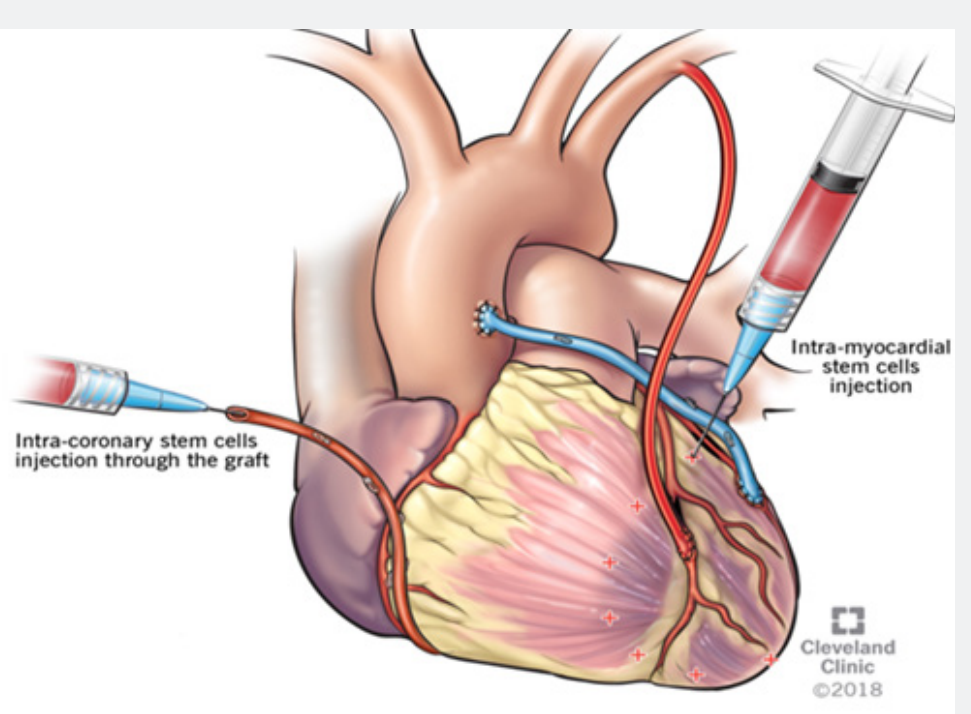

Figure 1: Route of Bone Marrow Stem Cells Injection During CABG.

This method of BMSCs delivery is performed by direct multiple injections of cell suspensions into target myocardial areas. The ischemic areas are identified preoperatively using nuclear imaging and echocardiography then visualized directly during the procedure. The prepared BMSC suspension is injected into the border zone of the target area after the graft-coronary anastomosis is completed $[39,40]$. That was the method used by Stamm et al. in the first trial of combined CABG and BMSC therapy [41]. The injections can also be performed at infarcted areas that will not be mechanically revascularized during CABG due to lack of graftable coronary vessels. This method is considered to be the most reliable and the widest used method of BMSCs delivery during CABG [42]. However, one of its drawbacks is the risk of perforation at the injection site. Also, cell leakage and clumping during injection may cause nonspecific delivery and prevent uniform cell distribution as well [43] (Figure 1).

\section{Intracoronary Infusion}

Infusing the BMSCs via coronary arteries can be performed by injecting the cell suspensions via the saphenous vein graft after distal anastomosis is finished, or injecting it through distal left anterior descending artery before completing the distal anastomosis with the internal thoracic artery. The arteries used for the injection are determined preoperatively by identifying the anatomical feeding vessels of the infarcted area [44]. Unlike intramyocardial injection, this method requires the presence of graftable coronary vessels feeding the target area. The intracoronary infusion has been the most practiced method of BMSCs delivery in catheter-based studies for interventional cardiology [45].

\section{Retrograde Coronary Sinus Delivery}

The coronary sinus has been utilized for retrograde delivery of cardioplegic solution in cardiac surgery. A similar technique can be used to deliver the BMSCs via retrograde infusion through the coronary sinus to the coronary veins [46]. Although this method has a theoretical advantage of more homogeneous cell delivery, it is the least investigated method of delivery [47].

\section{Potential Mechanism of Action}

In spite of the great expansion of knowledge and experience that has been achieved in the field of regenerative medicine, a major gap still persists in understanding the exact mechanisms of action of cell-based therapies in cardiac regenerative medicine. The oldest presumed mechanism was the direct cell transdifferentiation from BMSCs to contracting mature cardiac 
myocytes replacing the dead ones and restoring the cardiac functions [7]. Another theory was developed later depending on the neovascularization capacity of the transplanted BMSCs. Neovascularization may be beneficial in ischemic situations by increasing blood vessel density and providing a well-developed network of collateral vessels for maintaining adequate blood supply to the ischemic area. However, these benefits are less clear for old infarcted areas with no viable myocardium [48]. Later the paracrine hypothesis was developed referring to the capacity of transplanted BMSCs to release signals and growth factors into extracellular matrix affecting the neighboring cells [49]. Examples of processes associated with the paracrine effect of transplanted BMSCs may include neovascularization, cytokine-induced myocyte growth, stimulation of endogenous myocardial stem cells, preventing overstretch of myocytes and maintain proper electrical behavior of myocardium by extracellular matrix remodeling, inhibition of cardiomyocytes hypertrophic response, and cell fusion between resident myocytes and transplanted BMSCs [50-52].

\section{Types of Stem Cells for Cardiac Therapy}

The stem cell population is either embryonic (pluripotent) cells or adult somatic (multipotent) cells. Using re-programming techniques, the genes that are produced in the embryonic cells can be injected into adult cells to reproduce immature cells that possess characters resembling the embryonic ones, which are then called induced pluripotent cells. The stem cells can be driven from peripheral blood, fatty tissue, muscle, cardiac muscle, and bone marrow. The ideal stem cells must not carry any oncogenic effects on the host. They must be immune inert and not arrhythmogenic or cause any serious life threating condition. They should be easily and cheaply gathered, treated and delivered. They should be able to migrate and integrate into the host tissues and be available to be used anytime as an "offthe-shelf" product for the emergency cases and should have a remarkable effect on the clinical outcome of the patients. Their collection and usage should not be morally and lawfully dubious [53].

\section{Bone Marrow Extracted Cells}

The primitive endothelial progenitor cell cells can migrate from the bone marrow through the blood to the regions of ischemia and take a role of the regenerations of blood vessels and mature cardiac cells, hence the interest of using the bone marrow stem cells in treating IHD patients has emerged [54]. The bone marrow provides a source for different populations of stem cells such as non- hematopoietic, hematopoietic cells and progenitor cells. Collection of bone marrow-derived cells is feasible clinically by aspiration of the bone marrow or by extraction of the mononuclear cells from the blood to get the unfractionated bone marrow stem cells which include hematopoietic stem cells, endothelial progenitor cells, and mesenchymal stem cells. The unfractionated bone marrow stem cells can be further treated and purified using noncomplex techniques to get the subgroups of differentiated cells according to the surface expressed genes which are fractionated CD34+ bone marrow cells and fractionated CD133+ bone marrow cells. The unfractionated stem cells are a safe and feasible option that can be used in many heart diseases including IHD and HF. However, the results of their usage are still controversial $[33,55]$.

\section{Embryonic Stem Cells}

The embryonic stem cells are derived from the inner cell mass of the blastocyst. Theoretically, they offer the ideal profile for stem cell therapy due to its pluripotency, clonality, and self-renewal abilities. However, they still carry a significant neoplastic risk due to its virtual ability to differentiate to any cell type [56]. They can be differentiated morphologically into cardiomyocytes, however, they lack a true mature phenotype. Their transplantation in an animal model led to cardiac functional improvement in an induced infarction study [57]. In addition to its significant neoplastic risk, embryonic stem cells carry a lot of ethical and moral controversy. These two factors might limit the use of embryonic stem cells in clinical settings.

\section{Cardiac Stem Cells and Progenitor Cells}

C-kit+ cardiac stem cells are characterized by the presence of the surface expressed c-kit+ markers. Some authors had adopted the trans-differentiate into cardiomyocytes as a mechanism of action by which they act. Others advocated the paracrine mechanism of action by which these stem cells can act [58]. Animal studies had demonstrated that the injection of human cardiac cells in the induced ischemic heart model had improved the contractility of the myocardium and reduced the postinfarction ventricular dilatation. Additionally, it had changed the molecular and genetic properties of the cardiac cells. It had been shown to improve the structural and physiological recovery of the cardiac cells $[59,60]$. Clinically, injecting the cardiac stem cells, which were collected in the operating room, three months after coronary bypass operation in postinfarction patients either in the graft or in the coronary ostium of the native coronary vessel supplying the ischemic area had shown a remarkable improvement of the pump function of the heart as well as improvement in the clinical outcome and the quality of life of these patients. The cardiac stem cells harvesting and injection was found to be feasible and safe [61]

Ex vivo culture of cardiac biopsies has evolved structurally peculiar types of cells that were considered as primitive cardiac cells, tend to be globular in shape and could improve the structural and physiological recovery of the diseased cardiac cells. They can express a variety of surface antigens like the ones expressed by endothelial cells, mesenchymal stem cells, stem cells, and embryonic cells $[27,62]$. The animal model showed that the injection of the cardiosphere-derived cells had improved the ventricular function, the viability of the myocardium, the hemodynamics proprieties and reduce the infracted size $[63,64]$. Clinically, the CADUCEUS trial had demonstrated the safety of this 
approach. In addition, the exercise capacity of patients treated with cardiosphere-derived cells had improved. Radiologically, follow-up MRI showed improvement in the myocardial viability, contractility and wall thickness reducing the scar tissue [65].

\section{Allogenic Stem Cell Therapy}

Most of the clinical trials for combined CABG and BMSC therapy have investigated autologous cell preparations. Considering the advantage of avoiding immunologic rejection, autologous sources of stem cells have been more attractive for researchers. Nevertheless, autologous stem cell therapy is associated with serious limitations. Especially for patients with serious IHD who are a candidate for CABG, time is a crucial factor that cannot be wasted on tissue harvesting, cell processing, and quality control; which usually are not available at the same facility where the patient will undergo his CABG surgery. In addition, stem cell growth properties may be affected by age as well as other comorbidities that are usually found in those patients $[53,66]$. On the other hand, allogenic sources of stem cells provide "off-the-shelf" and safe solution for those patients being harvested from healthy young donors. Allogeneic stem cell therapy has been proven to be safe and clinical trials combining it with CABG have been started as well [67-69].

\section{References}

1. Benjamin EJ, Virani SS, Callaway CW, Chamberlain AM, Chang AR, et al. (2018) Heart Disease and Stroke Statistics-2018 Update: A Report From the American Heart Association. Circulation 137(12): e67-e492.

2. Go AS, Mozaffarian D, Roger VL, Benjamin EJ, Berry JD, et al. (2014) Heart disease and stroke statistics--2014 update: a report from the American Heart Association. Circulation 129(3): e28-e292.

3. Fraccarollo D, Galuppo P, Bauersachs J (2012) Novel therapeutic approaches to post-infarction remodelling. Cardiovasc Res 94(2): 293303.

4. Dorn GW (2009) Novel pharmacotherapies to abrogate postinfarction ventricular remodeling. Nat Rev Cardiol 6(4): 283-291.

5. Stewart S, Ekman I, Ekman T, Oden A, Rosengren A (2010) Population impact of heart failure and the most common forms of cancer: a study of 1162309 hospital cases in Sweden (1988 to 2004) Circ Cardiovasc Qual Outcomes 3(6): 573-580.

6. Chen J, Normand SL, Wang Y, Krumholz HM (2011) National and regional trends in heart failure hospitalization and mortality rates for Medicare beneficiaries, 1998-2008. JAMA 306(15): 1669-1678.

7. Orlic D, Kajstura J, Chimenti S, Jakoniuk I, Anderson SM, et al. (2001) Bone marrow cells regenerate infarcted myocardium. Nature 410(6829): 701-705.

8. Lang CI, Wolfien M, Langenbach A, Müller P, Wolkenhauer O, et al. (2017) Cardiac Cell Therapies for the Treatment of Acute Myocardial Infarction: A Meta-Analysis from Mouse Studies. Cell Physiol Biochem 42(1): 254-268.

9. Donndorf P, Kundt G, Kaminski A, Yerebakan C, Liebold A, et al. (2011) Intramyocardial bone marrow stem cell transplantation during coronary artery bypass surgery: a meta-analysis. J Thorac Cardiovasc Surg 142(4): 911-920.

10. Buja LM (2005) Myocardial ischemia and reperfusion injury. Cardiovasc Pathol 14(4): 170-175.
11. Frangogiannis NG (2006) The mechanistic basis of infarct healing. Antioxid Redox Signal 8(11-12): 1907-1939.

12. Assomull RG, Prasad SK, Lyne J, Smith G, Burman ED, et al. (2006) Cardiovascular magnetic resonance, fibrosis, and prognosis in dilated cardiomyopathy. J Am Coll Cardiol 48(10): 1977-1985.

13. Spinale FG (2007) Myocardial matrix remodeling and the matrix metalloproteinases: influence on cardiac form and function. Physiol Rev 87(4): 1285-1342.

14. Fyhrquist F, Saijonmaa $O$ (2008) Plasma renin activity: an assay with ongoing clinical relevance. Clin Chem 54(8): 1400.

15. Kupari M, Turto H, Lommi J (2004) Diagnosing heart failure in aortic valve stenosis. J Intern Med 256(5): 381-387.

16. Dunselman PH, Kuntze CE, van Bruggen A, Beekhuis H, Piers B, et al. (1988) Value of New York Heart Association classification, radionuclide ventriculography, and cardiopulmonary exercise tests for selection of patients for congestive heart failure studies. Am Heart J 116(6 Pt 1): $1475-1482$.

17. Campeau L (2002) The Canadian Cardiovascular Society grading of angina pectoris revisited 30 years later. Can J Cardiol 18(4): 371-379.

18. McMurray JJ, Adamopoulos S, Anker SD, et al. (2012) ESC guidelines for the diagnosis and treatment of acute and chronic heart failure 2012: The Task Force for the Diagnosis and Treatment of Acute and Chronic Heart Failure 2012 of the European Society of Cardiology. Developed in collaboration with the Heart Failure Association (HFA) of the ESC. Eur J Heart Fail 14(8): 803-869.

19. Jencks SF, Williams MV, Coleman EA (2009) Rehospitalizations among patients in the Medicare fee-for-service program. N Engl J Med 360(14): 1418-1428.

20. Chien KR, Domian IJ, Parker KK (2008) Cardiogenesis and the complex biology of regenerative cardiovascular medicine. Science 322(5907): 1494-1497.

21. Ptaszek LM, Mansour M, Ruskin JN, Chien KR (2012) Towards regenerative therapy for cardiac disease. Lancet 379(9819): 933-942.

22. Laugwitz KL, Moretti A, Lam J, Gruber P, Chen Y, et al. (2005) Postnatal isl1+ cardioblasts enter fully differentiated cardiomyocyte lineages. Nature 433(7026): 647-653.

23. Bu L, Jiang X, Martin-Puig S, Caron L, Zhu S, et al. (2009) Human ISL1 heart progenitors generate diverse multipotent cardiovascular cell lineages. Nature 460(7251): 113-117.

24. Quaini F, Cigola E, Lagrasta C, Saccani G, Quaini E, et al. (1994) Endstage cardiac failure in humans is coupled with the induction of proliferating cell nuclear antigen and nuclear mitotic division in ventricular myocytes. Circ Res 75(6): 1050-1063.

25. Beltrami AP, Urbanek K, Kajstura J, Yan SM, Finato N et al. (2001) Evidence that human cardiac myocytes divide after myocardial infarction. N Engl J Med 344(23): 1750-1757.

26. Beltrami AP, Barlucchi L, Torella D, Baker M, Limana F, et al. (2003) Adult cardiac stem cells are multipotent and support myocardial regeneration. Cell 114(6): 763-776.

27. Messina E, De Angelis L, Frati G, Morrone S, Chimenti S, et al. (2004) Isolation and expansion of adult cardiac stem cells from human and murine heart. Circ Res 95(9): 911-921.

28. Bergmann O, Bhardwaj RD, Bernard S, Zdunek S, Barnabé-Heider F, et al. (2009) Evidence for cardiomyocyte renewal in humans. Science 324(5923): 98-102.

29. Kloner RA, Arimie RB, Kay GL, Cannom D, Matthews R, et al. (2001) Evidence for stunned myocardium in humans: a 2001 update. Coron Artery Dis 12(5): 349-356. 


\section{Open Access Journal of Surgery}

30. Veterans Administration Coronary Artery Bypass Surgery Cooperative Study Group (1984) Eleven-year survival in the Veterans Administration randomized trial of coronary bypass surgery for stable angina. $\mathrm{N}$ Engl J Med 311(21): 1333-1339.

31. Varnauskas E (1988) Twelve-year follow-up of survival in the randomized European Coronary Surgery Study. N Engl J Med 319(6): 332-337.

32. Yusuf S, Zucker D, Peduzzi P, Fisher LD, Takaro T, et al. (1994) Effect of coronary artery bypass graft surgery on survival: overview of 10-year results from randomised trials by the Coronary Artery Bypass Graft Surgery Trialists Collaboration. Lancet 344(8922): 563-570.

33. Windecker S, Stortecky S, Stefanini GG, da Costa BR, Rutjes AW, et al (2014) Revascularisation versus medical treatment in patients with stable coronary artery disease: network meta-analysis. BMJ 348: g3859.

34. Jones RH, Velazquez EJ, Michler RE (2009) Coronary bypass surgery with or without surgical ventricular reconstruction. N Engl J Med 360(17): 1705-1717.

35. Greenberg BH, Anand IS, Burnett JC, Chin J, Dracup KA, et al. (2012) The Heart Failure Society of America in 2020: a vision for the future. Card Fail 18(2): 90-93.

36. Fisher SA, Doree C, Mathur A, Taggart DP, Martin-Rendon E (2016) Stem cell therapy for chronic ischaemic heart disease and congestive heart failure. Cochrane Database Syst Rev 12: CD007888.

37. Steinhoff G, Nesteruk J, Wolfien M, Kundt G4; PERFECT Trial Investigators Group, et al. (2017) Cardiac Function Improvement and Bone Marrow Response -: Outcome Analysis of the Randomized PERFECT Phase III Clinical Trial of Intramyocardial CD133(+) Application After Myocardial Infarction. E Biomedicine 22: 208-224.

38. Noiseux N, Mansour S, Weisel R, Stevens LM4, Der Sarkissian S, et al. (2016) The IMPACT-CABG trial: A multicenter, randomized clinical trial of CD133(+) stem cell therapy during coronary artery bypass grafting for ischemic cardiomyopathy. J Thorac Cardiovasc Surg 152(6) 1582-1588

39. Stamm C, Kleine HD, Choi YH, Lauffs JA, Lorenzen B et al. (2007) Intramyocardial delivery of CD133+ bone marrow cells and coronary artery bypass grafting for chronic ischemic heart disease: safety and efficacy studies. J Thorac Cardiovasc Surg 133(3): 717-725.

40. Kaminski A, Steinhoff G (2008) Current status of intramyocardial bone marrow stem cell transplantation. Semin Thorac Cardiovasc Surg 20(2): 119-125.

41. Stamm C, Westphal B, Kleine HD, Petzsch M, Kittner C, et al. (2003) Autologous bone-marrow stem-cell transplantation for myocardial regeneration. Lancet 361(9351): 45-46.

42. Dimmeler S, Zeiher AM, Schneider MD (2005) Unchain my heart: the scientific foundations of cardiac repair. J Clin Invest 115(3): 572-583.

43. Kocher AA, Schlechta B, Gasparovicova A, Wolner E, Bonaros N (2007) Stem cells and cardiac regeneration. Transpl Int 20(9): 731-746.

44. Hu S, Liu S, Zheng Z, Yuan X, Li L, et al. (2011) Isolated coronary artery bypass graft combined with bone marrow mononuclear cells delivered through a graft vessel for patients with previous myocardial infarction and chronic heart failure: a single-center, randomized, double-blind, placebo-controlled clinical trial. J Am Coll Cardiol 57 (24): 2409-2415.

45. Dib N, Menasche P, Bartunek JJ, Zeiher AM, Terzic A, et al. (2010) Recommendations for successful training on methods of delivery of biologics for cardiac regeneration: a report of the International Society for Cardiovascular Translational Research. JACC Cardiovasc Interv 3(3): 265-275.

46. Giordano FJ (2003) Retrograde coronary perfusion: a superior route to deliver therapeutics to the heart?*. J Am Coll Cardiol 42(6): 11291131.
47. Raake P, von Degenfeld G, Hinkel R, Vachenauer R, Sandner T, et al. (2004) Myocardial gene transfer by selective pressure-regulated retroinfusion of coronary veins: comparison with surgical and percutaneous intramyocardial gene delivery. J Am Coll Cardiol 44(5): 1124-1129.

48. Kawamoto A, Iwasaki H, Kusano K, Murayama T, Oyamada A, et al. (2006) CD34-positive cells exhibit increased potency and safety for therapeutic neovascularization after myocardial infarction compared with total mononuclear cells. Circulation 114(20): 2163-2169.

49. Mirotsou M, Jayawardena TM, Schmeckpeper J, Gnecchi M, Dzau V] (2011) Paracrine mechanisms of stem cell reparative and regenerative actions in the heart. J Mol Cell Cardiol 50(2): 280-289.

50. Anversa P, Kajstura J, Nadal-Ginard B, Leri A (2003) Primitive cells and tissue regeneration. Circ Res 92(6): 579-582.

51. Alvarez-Dolado M, Pardal R, Garcia-Verdugo JM, Fike JR, Lee HO, et al. (2003) Fusion of bone-marrow-derived cells with Purkinje neurons, cardiomyocytes and hepatocytes. Nature 425(6961): 968-973.

52. Tse HF, Siu CW, Zhu SG, Songyan L, Zhang QY, et al. (2007) Paracrine effects of direct intramyocardial implantation of bone marrow derived cells to enhance neovascularization in chronic ischaemic myocardium. Eur J Heart Fail 9(8): 747-753.

53. Malliaras K, Kreke M, Marban E (2011) The stuttering progress of cell therapy for heart disease. Clin Pharmacol Ther 90(4): 532-541.

54. Menasche P (2011) Cardiac cell therapy: lessons from clinical trials. J Mol Cell Cardiol 50(2): 258-265.

55. Behfar A, Crespo-Diaz R, Terzic A, Gersh BJ (2014) Cell therapy for cardiac repair--lessons from clinical trials. Nat Rev Cardiol 11(4): 232 246.

56. Nussbaum J, Minami E, Laflamme MA, Virag JA, Ware CB, et al. (2007) Transplantation of undifferentiated murine embryonic stem cells in the heart: teratoma formation and immune response. FASEB J 21(7): 1345-1357.

57. Menard C, Hagege AA, Agbulut O, Barro M, Morichetti MC, et al. (2005) Transplantation of cardiac-committed mouse embryonic stem cells to infarcted sheep myocardium: a preclinical study. Lancet 366(9490): 1005-1012.

58. Senyo SE, Steinhauser ML, Pizzimenti CL, Yang VK, Cai L et al. (2013) Mammalian heart renewal by pre-existing cardiomyocytes. Nature 493(7432): 433-436

59. Rota M, Padin-Iruegas ME, Misao Y, De Angelis A, Maestroni S, et al. (2008) Local activation or implantation of cardiac progenitor cells rescues scarred infarcted myocardium improving cardiac function. Circ Res 103(1): 107-116.

60. Bolli R, Tang XL, Sanganalmath SK, Rimoldi O, Mosna F, et al. (2013) Intracoronary delivery of autologous cardiac stem cells improves cardiac function in a porcine model of chronic ischemic cardiomyopathy. Circulation 128(2): 122-131.

61. Bolli R, Chugh AR, D’Amario D (2011) Cardiac stem cells in patients with ischaemic cardiomyopathy (SCIPIO): initial results of a randomised phase 1 trial. Lancet 378(9806): 1847-1857.

62. Davis DR, Kizana E, Terrovitis J (2010) Isolation and expansion of functionally-competent cardiac progenitor cells directly from heart biopsies. J Mol Cell Cardiol 49(2): 312-321.

63. Malliaras K, Li TS, Luthringer D, Terrovitis J, Cheng K, et al. (2012) Safety and efficacy of allogeneic cell therapy in infarcted rats transplanted with mismatched cardiosphere-derived cells. Circulation 125(1): 100112.

64. Johnston PV, Sasano T, Mills K, Evers R, Lee ST, et al. (2009) Engraftment, differentiation, and functional benefits of autologous cardiosphere-derived cells in porcine ischemic cardiomyopathy. Circulation 120(12): 1075-1083. 
65. Makkar RR, Smith RR, Cheng K, Malliaras K, Thomson LE, et al. (2012) Intracoronary cardiosphere-derived cells for heart regeneration after myocardial infarction (CADUCEUS): a prospective, randomized phase 1 trial. Lancet 379(9819): 895-904.

66. Dimmeler S, Leri A (2008) Aging and disease as modifiers of efficacy of cell therapy. Circ Res 102(11): 1319-1330.

67. Hare JM, Fishman JE, Gerstenblith G, DiFede Velazquez DL, Zambrano JP, et al. (2012) Comparison of allogeneic vs autologous bone marrow-derived mesenchymal stem cells delivered by transendocardial injection in patients with ischemic cardiomyopathy: The POSEIDON randomized trial. JAMA 308(22): 2369-2379.

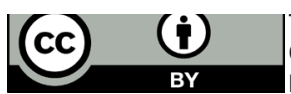

This work is licensed under Creative Commons Attribution 4.0 Licens DOI: 10.19080/OAJS.2019.10.555796
68. Anastasiadis K, Antonitsis P, Westaby S, Reginald A, Sultan S, et al. (2016) Implantation of a Novel Allogeneic Mesenchymal Precursor Cell Type in Patients with Ischemic Cardiomyopathy Undergoing Coronary Artery Bypass Grafting: An Open Label Phase IIa Trial. J Cardiovasc Transl Res 9(3): 202-213.

69. Higgins JPT, Green S, Cochrane Collaboration (2008) Cochrane handbook for systematic reviews of interventions. Wiley-Blackwell: Chichester, England.

\section{Your next submission with Juniper Publishers will reach you the below assets}

- Quality Editorial service

- Swift Peer Review

- Reprints availability

- E-prints Service

- Manuscript Podcast for convenient understanding

- Global attainment f or your research

- Manuscript accessibility in different formats ( Pdf, E-pub, Full Text, Audio)

- Unceasing customer service

Track the below URL for one-step submission https://juniperpublishers.com/online-submission.php 